\title{
Novel polyelectrolytes containing perfluorocyclobutane and triazole units: synthesis, characterization and properties
}

\author{
Yuanqin $\mathrm{Zhu}^{1}$, Haihua $\mathrm{Chen}^{2}$ and Chuanglong $\mathrm{He}^{1}$ \\ A new class of aryl trifluorovinyl ether monomers were designed and synthesized, and novel fluorinated polymers containing \\ perfluorocyclobutane and $1 \mathrm{H}-1,2,3$-triazole units were prepared from these monomers. These polymers were characterized by \\ nuclear magnetic resonance spectroscopy, thermo-gravimetric analysis and differential scanning calorimetry. The temperatures \\ of $5 \%$ weight loss of the polymers under nitrogen were up to $\sim 290{ }^{\circ} \mathrm{C}$, and the glass transition temperatures of the polymers \\ were in the range of $79-110^{\circ} \mathrm{C}$. These new polymers showed good solubility in common organic solvents such as dimethyl \\ sulfoxide and $\mathrm{N}, \mathrm{N}$-dimethylacetamide. In addition, the proton conductivity of the polymers was measured under anhydrous \\ conditions using impedance spectroscopy, and a maximum conductivity of $2.85 \mu \mathrm{S} \mathrm{cm}^{-1}$ was obtained at $200^{\circ} \mathrm{C}$.
}

Polymer Journal (2011) 43, 258-264; doi:10.1038/pj.2010.129; published online 22 December 2010

Keywords: fluorinated polymers; oligo(ethylene oxide); polyelectrolytes; triazole

\section{INTRODUCTION}

Proton-conducting polymers have attracted much attention as promising materials for membranes for fuel cells. The operation of proton exchange membrane fuel cells at medium temperatures $\left(100-200{ }^{\circ} \mathrm{C}\right)$ can provide many advantages, such as improved carbon monoxide tolerance, higher energy efficiency and simplified heat management. ${ }^{1-4}$ Thus far, many efforts have been made to develop proton-conducting materials for medium temperature fuel cells. ${ }^{5-8}$

One of these approaches involves finding compounds with an amphoteric nature to act as water substitutes. Recently, nitrogencontaining heterocyclic compounds, such as imidazole, pyrazole and benzimidazole, have been suggested as proton solvents for proton exchange membrane fuel cells, and they may also be covalently tethered to some suitable polymers to prepare fully polymeric materials. ${ }^{9-18}$ Liu et al. ${ }^{19}$ suggested that $1 H$-1,2,3-triazole has adequate electrochemical stability for fuel cell applications, and the $1 H-1,2,3-$ triazole groups immobilized on a polymer backbone may open up new avenues in the design of polyelectrolytes. To date, several polymeric systems with tethered $1 H-1,2,3$-triazole moieties have been evaluated as polyelectrolytes. ${ }^{13-17}$ However, most of these polymers derived from polyacrylate or polyethylene may have issues related to their electrochemical or dimensional stability for medium temperature fuel cells. During the past decade, partially fluorinated polymers containing perfluorocyclobutane (PFCB) rings have been developed. ${ }^{19-21}$ These polymers exhibit high-thermal/oxidative/mechanical stability, good chemical resistance and flexibility. In addition, it was recently reported that this type of polymer could be promising for use in the membranes of fuel cells. ${ }^{22,23}$ From this point of view, we have been trying to develop new partially fluorinated ionomers into which both PFCB and 1H-1,2,3-triazole units are incorporated. In these ionomers, triazole units are covalently grafted to the polymer backbone containing PFCB groups by flexible chains, which may increase the mobility of triazole units to facilitate proton transfer.

In this work, we report the synthesis and characterization of novel polymers containing PFCB and $1 H$-1,2,3-triazoles moieties. The polymer backbones and $1 H-1,2,3$-triazoles units are connected by flexible oligo(ethylene oxide) chains. These polymers were prepared from novel aromatic trifluorovinyl ether monomers (6) via thermal $(2 \pi+2 \pi)$ cyclopolymerization. The preparation process, the corresponding composition and structure, and some physical properties of these polymers were investigated.

\section{EXPERIMENTAL PROCEDURE}

Materials

All chemicals were purchased from Sigma-Aldrich (Sigma-Aldrich Shanghai Trading Co. Ltd., Shanghai, China) with the exception of 1,2-dibromotetrafluoroethane (Shanghai Sinofluoro Scientific Co., Ltd, Shanghai, China). Acetonitrile and dimethyl sulfoxide (DMSO) were purified by standard methods before use. Zinc turnings were activated by treating with $5 \%$ aqueous hydrochloric acid. Propargyl mono-terminated oligo(ethylene oxide)s (3) and azidomethyl pivalate were prepared using previously published methods. ${ }^{24,25}$ Other reagents or materials were used as received.

${ }^{1}$ Department of Chemistry, College of Chemistry, Chemical Engineering and Biotechnology, Donghua University, Shanghai, PR China and ${ }^{2}$ Department of Applied Physics, College of Physical Science and Technology, Guangxi University, Guangxi, PR China

Correspondence: Dr Y Zhu or Associate Professor C He, College of Chemistry, Chemical Engineering and Biotechnology, Donghua University, 2999 North Renmin Road, Shanghai 201620, PR China.

E-mail: david1005@mail.dhu.edu.cn or hc|@dhu.edu.cn

Received 17 August 2010; revised 3 November 2010; accepted 8 November 2010; published online 22 December 2010 


\section{Measurements}

Gas chromatography/mass spectrometry was recorded on a Finnigan-MAT8430 (Thermo Finnigan MAT GmbH, Bremen, Germany) instrument using EI ionization at $70 \mathrm{eV}$. Elemental analysis was carried out on a Carlo-Erba1106 system (Elementar Analysensysteme GmbH, Hanau, Germany). Infrared spectra (IR) were obtained on a Thermo Electron Nicolet Avatar 360 FT-IR spectrometer (Thermo Fisher Scientific Inc., Waltham, MA, USA). ${ }^{1} \mathrm{H}$ nuclear magnetic resonance (NMR; $400 \mathrm{MHz}),{ }^{13} \mathrm{C}$ NMR $(100 \mathrm{MHz})$ and ${ }^{19} \mathrm{~F}$ NMR $(376 \mathrm{MHz})$ spectra were recorded on a Bruker Ultrashield 400 spectrometer (Bruker BioSpin AG, Fällanden, Switzerland). The relative molecular weights and distributions were measured with a Viscotek VE2001 GPC max system (Malvern Instruments, Worcestershire, UK). The system was calibrated with polystyrene standards. Differential scanning calorimetry (DSC) and thermo-gravimetric analysis (TGA) were conducted on a PerkinElmer 7 system (PerkinElmer, Waltham, MA, USA). Samples were heated from -50 to $250^{\circ} \mathrm{C}$ for DSC and $50-800{ }^{\circ} \mathrm{C}$ for TGA at $10^{\circ} \mathrm{C} \mathrm{min}^{-1}$ under nitrogen. Proton conductivity of the polymers was measured using a previously published method. ${ }^{17}$

\section{Synthesis of monomers (6)}

Preparation of 1,3-bis(2-bromotetrafluoroethoxy)anisole (1). A mixture of 5-methoxyresorcinol $(14.0 \mathrm{~g}, 0.100 \mathrm{~mol}), 1,2$-dibromotetrafluoroethane $(77.7 \mathrm{~g}$, $0.300 \mathrm{~mol})$ and $\mathrm{Cs}_{2} \mathrm{CO}_{3}(97.8 \mathrm{~g}, 0.300 \mathrm{~mol})$ in dry DMSO $(250 \mathrm{ml})$ was stirred for 3 days at $50^{\circ} \mathrm{C}$. After cooling to room temperature, $\mathrm{H}_{2} \mathrm{O}(300 \mathrm{ml})$ and $\mathrm{CH}_{2} \mathrm{Cl}_{2}(100 \mathrm{ml})$ were added. The aqueous phase was separated and washed with $\mathrm{CH}_{2} \mathrm{Cl}_{2}(2 \times 20 \mathrm{ml})$. The combined organic phases were washed with $\mathrm{H}_{2} \mathrm{O}$ $(2 \times 30 \mathrm{ml})$, brine $(2 \times 20 \mathrm{ml})$, and then dried over anhydrous $\mathrm{MgSO}_{4}$. After the removal of the solvent, the residue was purified by silica column chromatography using hexane to give compound $\mathbf{1}$ as a liquid $(30.1 \mathrm{~g}, 61 \%)$

${ }^{1} \mathrm{H}$ NMR $\left(\mathrm{CDCl}_{3}\right.$; p.p.m.) $\delta 6.71(\mathrm{~s}, 3 \mathrm{H}), 3.82(\mathrm{~s}, 3 \mathrm{H}) .{ }^{13} \mathrm{C} \mathrm{NMR}\left(\mathrm{CDCl}_{3}\right.$; p.p.m.) $\delta 161.1,149.8,115.8(\mathrm{tt}, 1 \mathrm{C}), 113.4(\mathrm{tt}, 1 \mathrm{C}), 107.5,106.3,56.0 .{ }^{19} \mathrm{~F}$ NMR $\left(\mathrm{CDCl}_{3}\right.$; p.p.m.) $\delta-67.9$ (t, 1F), -86.0 (t, 1F). MS: $m / z$ 500, 498, 496. Anal. calcd for $\mathrm{C}_{11} \mathrm{H}_{6} \mathrm{Br}_{2} \mathrm{~F}_{8} \mathrm{O}_{3}$ : C, 26.53\%; H, $1.21 \%$. Found: C, $26.47 \%$; $\mathrm{H}, 1.17 \%$.

Preparation of 1,3-bis(2-bromotetrafluoroethoxy)phenol (2). To a solution of 1 $(10 \mathrm{~g}, 20 \mathrm{mmol})$ in anhydrous $\mathrm{CH}_{2} \mathrm{Cl}_{2}(50 \mathrm{ml})$, boron tribromide in $\mathrm{CH}_{2} \mathrm{Cl}_{2}$ $(1 \mathrm{M}, 60 \mathrm{ml})$ was added slowly with stirring at $0{ }^{\circ} \mathrm{C}$. The resulting mixture was allowed to warm to room temperature and stirred for $48 \mathrm{~h}$. The solution was hydrolyzed by carefully adding $\mathrm{H}_{2} \mathrm{O}(50 \mathrm{ml})$. The aqueous phase was separated and washed with $\mathrm{CH}_{2} \mathrm{Cl}_{2}(2 \times 10 \mathrm{ml})$. The combined organic phases were washed with $5 \%$ aqueous $\mathrm{NaHCO}_{3}(2 \times 10 \mathrm{ml})$ and $\mathrm{H}_{2} \mathrm{O}(2 \times 10 \mathrm{ml})$ and dried over anhydrous $\mathrm{MgSO}_{4}$. After removal of the solvent, the residue was purified by silica column chromatography using EtOAc-hexane $(1: 6, \mathrm{v} / \mathrm{v})$ to give compound 2 as a liquid $(9.3 \mathrm{~g}, 98 \%)$.

${ }^{1} \mathrm{H}$ NMR $\left(\mathrm{CDCl}_{3}\right.$; p.p.m.) $\delta 6.71(\mathrm{t}, 3 \mathrm{H}), 5.85(\mathrm{~s}, 1 \mathrm{H}) .{ }^{13} \mathrm{C}$ NMR $\left(\mathrm{CDCl}_{3}\right.$; p.p.m.) $\delta 157.1,149.9,115.8(\mathrm{tt}, 1 \mathrm{C}), 113.3(\mathrm{tt}, 1 \mathrm{C}), 107.7 .{ }^{19} \mathrm{~F} \mathrm{NMR}\left(\mathrm{CDCl}_{3}\right.$; p.p.m.) $\delta-68.3(\mathrm{t}, 1 \mathrm{~F}),-86.4(\mathrm{t}, 1 \mathrm{~F})$. IR (neat; $\left.\mathrm{cm}^{-1}\right) 3392(-\mathrm{OH})$. MS: $\mathrm{m} / \mathrm{z}$ 486, 484, 482. Anal. calcd for $\mathrm{C}_{10} \mathrm{H}_{4} \mathrm{Br}_{2} \mathrm{~F}_{8} \mathrm{O}_{3}$ : C, $24.82 \%$; $\mathrm{H}, 0.83 \%$. Found: $\mathrm{C}$, $24.80 \% ; \mathrm{H}, 0.82 \%$.

Preparation of compound 4. Compound $3(10 \mathrm{mmol})$ and azidomethyl pivalate $(1.57 \mathrm{~g}, 10 \mathrm{mmol})$ were suspended in tetrahydrofuran $(\mathrm{THF})-\mathrm{H}_{2} \mathrm{O}$ $(20 \mathrm{ml}, 1: 1, \mathrm{v} / \mathrm{v})$. To this mixture copper (II) sulfate pentahydrate $(0.125 \mathrm{~g}$, $0.5 \mathrm{mmol})$ and sodium ascorbate $(0.594 \mathrm{~g}, 3 \mathrm{mmol})$ were added. The mixture was stirred at room temperature for $48 \mathrm{~h}$. The resulting mixture was diluted with $\mathrm{H}_{2} \mathrm{O}(20 \mathrm{ml})$ and then extracted with EtOAc $(2 \times 20 \mathrm{ml})$. The combined organic layers were washed with water $(2 \times 10 \mathrm{ml})$ and brine $(2 \times 10 \mathrm{ml})$ and dried over anhydrous $\mathrm{MgSO}_{4}$. After the removal of solvent, the residue was purified by silica column chromatography using hexane-EtOAc $(1: 3, \mathrm{v} / \mathrm{v})$ to give compound $\mathbf{4}$ as a colorless oil.

Compound 4a: Yield 96\%. ${ }^{1} \mathrm{H}$ NMR $\left(\mathrm{CDCl}_{3}\right.$; p.p.m.) $\delta 7.80(\mathrm{~s}, 1 \mathrm{H}), 7.77(\mathrm{~d}$, $2 \mathrm{H}), 7.30(\mathrm{~d}, 2 \mathrm{H}), 6.19(\mathrm{~s}, 2 \mathrm{H}), 4.62(\mathrm{~s}, 2 \mathrm{H}), 4.11(\mathrm{t}, 2 \mathrm{H}), 3.53-3.65(\mathrm{~m}, 6 \mathrm{H})$, 2.39 (s, 3H), $1.14(\mathrm{~s}, 9 \mathrm{H})$. IR (neat; $\left.\mathrm{cm}^{-1}\right) 1745(\mathrm{C}=\mathrm{O})$. MS: $\mathrm{m} / \mathrm{z} 455$.

Compound 4b: Yield 93\%. ${ }^{1} \mathrm{H}$ NMR $\left(\mathrm{CDCl}_{3}\right.$; p.p.m.) $\delta 7.67(\mathrm{~d}, 1 \mathrm{H}), 7.54(\mathrm{~d}$, $2 \mathrm{H}), 7.13(\mathrm{~d}, 2 \mathrm{H}), 6.01(\mathrm{~s}, 2 \mathrm{H}), 4.43(\mathrm{~s}, 2 \mathrm{H}), 3.91(\mathrm{t}, 2 \mathrm{H}), 3.33-3.45(\mathrm{~m}, 10 \mathrm{H})$, $2.19(\mathrm{~s}, 3 \mathrm{H}), 0.93$ (s, 9H). IR (neat; $\left.\mathrm{cm}^{-1}\right) 1744(\mathrm{C}=\mathrm{O}) . \mathrm{MS}: \mathrm{m} / \mathrm{z} 499$.
Compound 4c: Yield 92\%. ${ }^{1} \mathrm{H}$ NMR $\left(\mathrm{CDCl}_{3}\right.$; p.p.m.) $\delta 7.78(\mathrm{~d}, 1 \mathrm{H}), 7.74$ (d, 2H), 7.29 (d, 2H), $6.16(\mathrm{~s}, 2 \mathrm{H}), 4.63(\mathrm{~s}, 2 \mathrm{H}), 4.09(\mathrm{t}, 2 \mathrm{H}), 3.55-3.70$ $(\mathrm{m}, 14 \mathrm{H}), 2.38(\mathrm{~s}, 3 \mathrm{H}), 1.12(\mathrm{~s}, 9 \mathrm{H})$. IR (neat; $\left.\mathrm{cm}^{-1}\right) 1744(\mathrm{C}=\mathrm{O})$. MS: $\mathrm{m} / z 543$.

Preparation of compound 5. A mixture of $2(4.84 \mathrm{~g}, 0.01 \mathrm{~mol}), 4(0.01 \mathrm{~mol})$ and anhydrous $\mathrm{K}_{2} \mathrm{CO}_{3}(2.76 \mathrm{~g}, 0.02 \mathrm{~mol})$ in $\mathrm{CH}_{3} \mathrm{CN}(50 \mathrm{ml})$ was stirred at reflux for $48 \mathrm{~h}$. After the removal of the solvent, the residue was diluted with $\mathrm{H}_{2} \mathrm{O}$ and EtOAc. The organic layer was separated, and the aqueous layer was extracted with EtOAc $(2 \times 10 \mathrm{ml})$. The combined organic layers were washed with $\mathrm{H}_{2} \mathrm{O}$ $(2 \times 10 \mathrm{ml})$ and brine $(2 \times 10 \mathrm{ml})$ and dried over anhydrous $\mathrm{MgSO}_{4}$. After the removal of the solvent, the residue was purified by silica column chromatography using hexane-EtOAc $(2: 7, \mathrm{v} / \mathrm{v})$ to give compound $\mathbf{5}$ as a colorless oil.

Compound 5a: Yield $89 \% .{ }^{1} \mathrm{H}$ NMR $\left(\mathrm{CDCl}_{3}\right.$; p.p.m.) $\delta 7.79(\mathrm{~s}, 1 \mathrm{H}), 6.73(\mathrm{~d}$, $3 \mathrm{H}), 6.19(\mathrm{~s}, 2 \mathrm{H}), 4.68(\mathrm{~s}, 2 \mathrm{H}), 4.13(\mathrm{t}, 2 \mathrm{H}), 3.84(\mathrm{t}, 2 \mathrm{H}), 3.71(\mathrm{~s}, 4 \mathrm{H}), 1.16(\mathrm{~s}$,

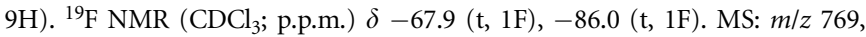
767, 765. Anal. calcd for $\mathrm{C}_{23} \mathrm{H}_{25} \mathrm{Br}_{2} \mathrm{~F}_{8} \mathrm{~N}_{3} \mathrm{O}_{7}$ : C, $36.00 \%$; H, 3.28\%. Found: $\mathrm{C}$, $35.95 \%$; H, 3.25\%

Compound 5b: Yield 87\%. ${ }^{1} \mathrm{H}$ NMR $\left(\mathrm{CDCl}_{3}\right.$; p.p.m.) $\delta 7.67(\mathrm{~s}, 1 \mathrm{H}), 6.72(\mathrm{~d}$, $3 \mathrm{H}), 6.20(\mathrm{~s}, 2 \mathrm{H}), 4.63(\mathrm{~s}, 2 \mathrm{H}), 4.11(\mathrm{t}, 2 \mathrm{H}), 3.82(\mathrm{t}, 2 \mathrm{H}), 3.64-3.68(\mathrm{~m}, 8 \mathrm{H})$, $1.14(\mathrm{~s}, 9 \mathrm{H}) .{ }^{19} \mathrm{~F}$ NMR $\left(\mathrm{CDCl}_{3}\right.$; p.p.m.) $\delta-67.9(\mathrm{t}, 1 \mathrm{~F}),-86.0(\mathrm{t}, 1 \mathrm{~F}) . \delta 21.3$. MS: $m / z$ 813, 811, 809. Anal. calcd for $\mathrm{C}_{25} \mathrm{H}_{29} \mathrm{Br}_{2} \mathrm{~F}_{8} \mathrm{~N}_{3} \mathrm{O}_{8}$ : C, 37.01\%; $\mathrm{H}, 3.60 \%$. Found: C, 36.97\%; H, 3.57\%.

Compound 5c: Yield 83\%. ${ }^{1} \mathrm{H}$ NMR $\left(\mathrm{CDCl}_{3}\right.$; p.p.m.) $\delta 7.69(\mathrm{~s}, 1 \mathrm{H}), 6.73(\mathrm{~d}$, $3 \mathrm{H}), 6.21(\mathrm{~s}, 2 \mathrm{H}), 4.64(\mathrm{~s}, 2 \mathrm{H}), 4.12(\mathrm{t}, 2 \mathrm{H}), 3.83(\mathrm{t}, 2 \mathrm{H}), 3.52-3.73(\mathrm{~m}, 12 \mathrm{H})$, $1.16(\mathrm{~s}, 9 \mathrm{H}) .{ }^{19} \mathrm{~F} \mathrm{NMR}\left(\mathrm{CDCl}_{3}\right.$; p.p.m.) $\delta-67.9(\mathrm{t}, 1 \mathrm{~F}),-86.0(\mathrm{t}, 1 \mathrm{~F}) . \mathrm{MS}: \mathrm{m} / \mathrm{z}$ 857, 855, 853. Anal. calcd for $\mathrm{C}_{27} \mathrm{H}_{33} \mathrm{Br}_{2} \mathrm{~F}_{8} \mathrm{~N}_{3} \mathrm{O}_{9}$ : C, 37.91\%; H, 3.89\%. Found: C, $37.88 \%$; H, 3.87\%

Preparation of compound 6 . To a flame-dried $100-\mathrm{ml}$ flask was added 5 ( $10 \mathrm{mmol})$, zinc $(1.95 \mathrm{~g}, 30 \mathrm{mmol})$ and $\mathrm{CH}_{3} \mathrm{CN}(30 \mathrm{ml})$. The resulting mixture was stirred at reflux for $48 \mathrm{~h}$. After removal of the solvent, the residue was diluted with $\mathrm{CH}_{2} \mathrm{Cl}_{2}$ and then filtered. The filtrate was washed with $\mathrm{H}_{2} \mathrm{O}$ and brine and dried over anhydrous $\mathrm{MgSO}_{4}$. After removal of the solvent, the residue was purified by silica column chromatography using hexane-EtOAc $(1: 3, \mathrm{v} / \mathrm{v})$ to give compound $\mathbf{6}$ as a colorless oil.

Compound 6a: Yield 77\%. MS: $m / z$ 569. Anal. calcd for $\mathrm{C}_{23} \mathrm{H}_{25} \mathrm{~F}_{6} \mathrm{~N}_{3} \mathrm{O}_{7}$ : C, 48.51\%; H, 4.43\%. Found: C, 48.50\%; H, 4.43\%.

Compound 6b: Yield 75\%. MS: $m / z$ 613. Anal. calcd for $\mathrm{C}_{25} \mathrm{H}_{29} \mathrm{~F}_{6} \mathrm{~N}_{3} \mathrm{O}_{8}$ : C, $48.94 \%$; H, 4.76\%. Found: C, 48.92\%; H, 4.75\%.

Compound 6c: Yield 72\%. MS: $m / z$ 657. Anal. calcd for $\mathrm{C}_{27} \mathrm{H}_{33} \mathrm{~F}_{6} \mathrm{~N}_{3} \mathrm{O}_{9}$ : C, $49.32 \%$; H, 5.06\%. Found: C, 49.30\%; H, 5.05\%.

\section{Synthesis of polymers 7 and 8}

Compound 6 ( $1 \mathrm{mmol})$ was added to a pre-dried $50-\mathrm{ml}$ flask. After three cycles of freeze-pump-thaw, the flask was heated at $190^{\circ} \mathrm{C}$ for $48 \mathrm{~h}$. After cooling to room temperature, the residue was dissolved in $\mathrm{CHCl}_{3}(10 \mathrm{ml})$ and then precipitated in hexane to give polymer 7 (90-95\%). To a solution of polymer $7(0.5 \mathrm{~g})$ in methanol $(10 \mathrm{ml})$ aqueous $\mathrm{NaOH}(1 \mathrm{M}, 1 \mathrm{ml})$ was added. The resulting mixture was stirred at room temperature for $12 \mathrm{~h}$ and subsequently neutralized with $5 \%$ aqueous hydrochloric acid. The solution was concentrated under vacuum and then dissolved in methanol $(5 \mathrm{ml})$. The resulting solution was triturated with excess diethyl ether. After filtration, the obtained solid was dried at $100^{\circ} \mathrm{C}$ for $24 \mathrm{~h}$ to give polymer $8(82-87 \%)$.

\section{RESULTS AND DISCUSSION}

\section{Monomer syntheses}

The preparation procedure for the monomers (6) is shown in Scheme 1. The synthesis of $\mathbf{1}$ initially focused on traditional methods. ${ }^{23-25}$ However, 6 was obtained in very low yield $(<20 \%)$. Most of the products were derived from the bromination of the benzene ring, which was confirmed by ${ }^{1} \mathrm{H}$ NMR and gas chromatography/mass spectrometry. Following a new route, ${ }^{26}$ the yield of $\mathbf{6}$ could be increased to $61 \%$. In this route, the phenoxides were generated in situ, which not only avoided using harsh conditions to prepare moisture sensitive phenoxides but also gave the desired products in higher yield. ${ }^{26}$ Using boron tribromide, demethylation of 1 was 


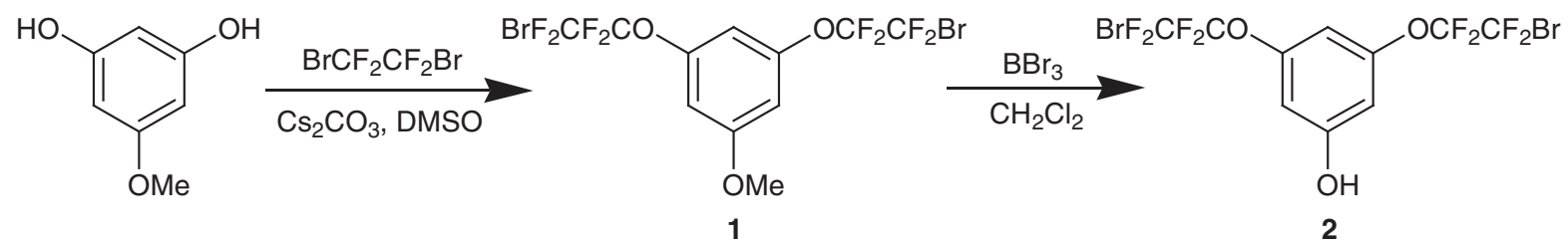

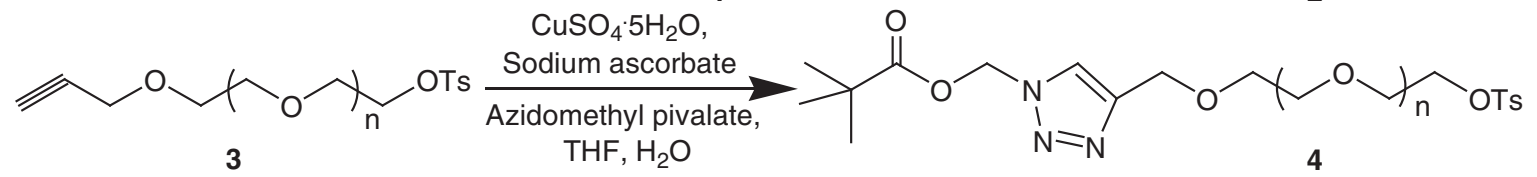

3a, $\mathrm{n}=1$

$3 b, n=2$

(2)

$4 a, n=1$

$4 \mathrm{~b}, \mathrm{n}=2$

$4 c, n=3$<smiles>CC(C)(C)C(=O)OCn1cc(COCCOCCOc2cc(OC(F)F)cc(OC(F)(F)F)c2)nn1</smiles>

$6 a, n=1$

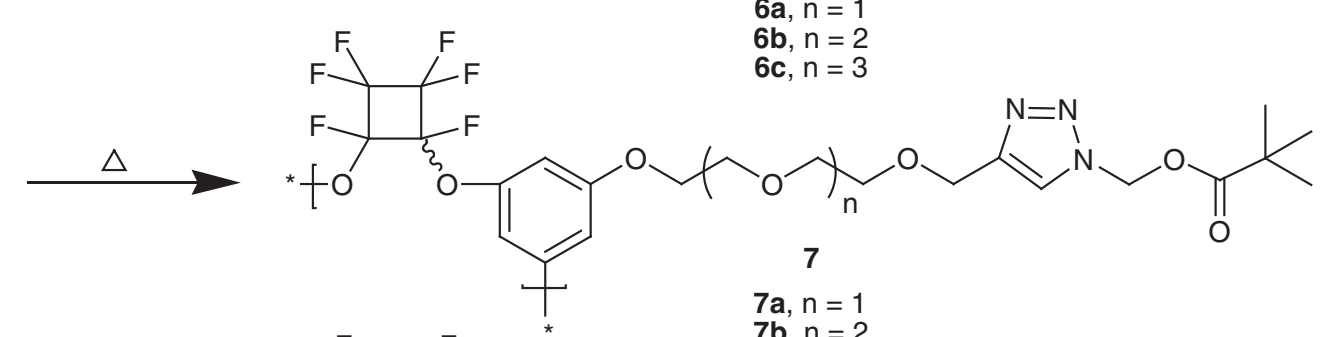

$7 a, n=1$

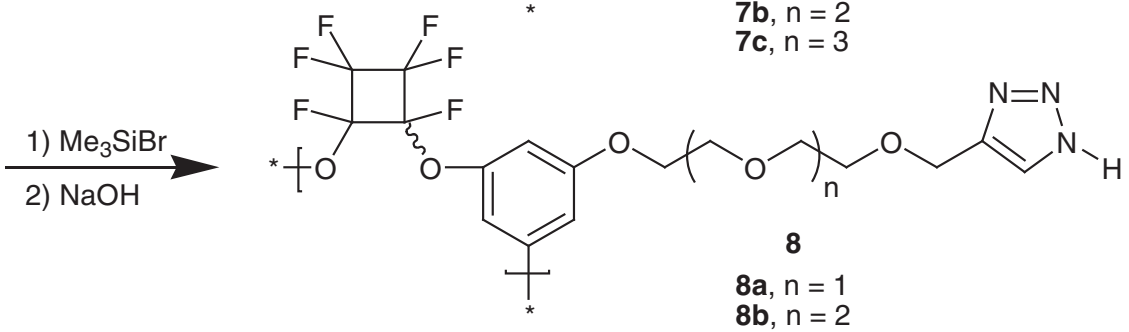

$8 b, n=2$

$8 c, n=3$

Scheme 1 Synthesis of polymer $\mathbf{8}$. DMSO, dimethyl sulfoxide; THF, tetrahydrofuran.

achieved successfully with relatively high yield ( $>96 \%$ ). Treatment of 3 with azidomethyl pivalate gave 4 in high yield (92-96\%) by a typical 'click' reaction. Using potassium carbonate as a base, the coupling reaction between 4 and 2 proceeded smoothly to give 5 in good yield (83-89\%). In the last step, $\boldsymbol{6}$ was synthesized from $\mathbf{5}$ by zinc-mediated elimination in anhydrous acetonitrile.

The composition and structure of $\mathbf{6}$ were confirmed by Fourier transform infrared (FT-IR), ${ }^{1} \mathrm{H}-,{ }^{13} \mathrm{C}$ - and ${ }^{19} \mathrm{~F}-\mathrm{NMR}$. Compound $\mathbf{6 b}$ is discussed as a typical example. In the ${ }^{1} \mathrm{H}$ NMR spectrum of $\mathbf{6 b}$ (Figure 1), the signals of methyl (at 1.13 p.p.m.) and ethylene (at 6.21 p.p.m.) in the pivaloyloxymethyl (POM) moieties were observed, and the singlet peak at 4.63 p.p.m. indicated the two protons adjacent to the triazole ring. In the ${ }^{13} \mathrm{C}$ NMR spectrum of $6 \mathbf{b}$ (Figure 2), the typical signals of $-\mathrm{OCF}=\mathrm{CF}_{2}$ groups were detected. The signals between 134.0 and 135.5 p.p.m. and 143.0 and 151.5 p.p.m. were attributed to the units of $-\mathrm{OCF}=$ and $=\mathrm{CF}_{2}$, respectively. These peaks overlapped with the signals of the carbon atoms in triazole rings, which appeared at 147.2 and 135.5 p.p.m. In addition, the four peaks at 26.9, 38.9, 74.2 and 177.0 p.p.m. were assigned to the carbon atoms in the POM moiety. The ${ }^{19} \mathrm{~F}$ NMR spectrum (Figure 3a) exhibited three doublets centered at $-119.0,-125.7$ and -134.6 p.p.m., which were assigned to the fluorine atoms in $\mathrm{OCF}=\mathrm{CF}_{2}$. Figure $5 \mathrm{a}$ displays the FT-IR spectrum of $\mathbf{6 b}$. The sharp band at $1832 \mathrm{~cm}^{-1}$ is the typical signal of $-\mathrm{OCF}=\mathrm{CF}_{2}$ groups, and the strong band at $1746 \mathrm{~cm}^{-1}$ was attributed to the carbonyl in the POM moieties. The characterization of 6 by gas chromatography/mass spectrometry and elemental analysis further confirmed the successful synthesis of the high-purity monomers. 


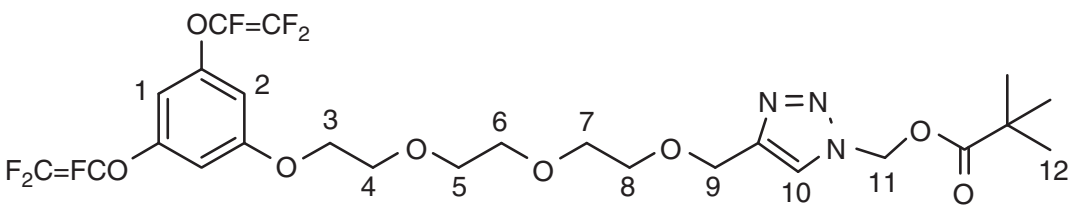

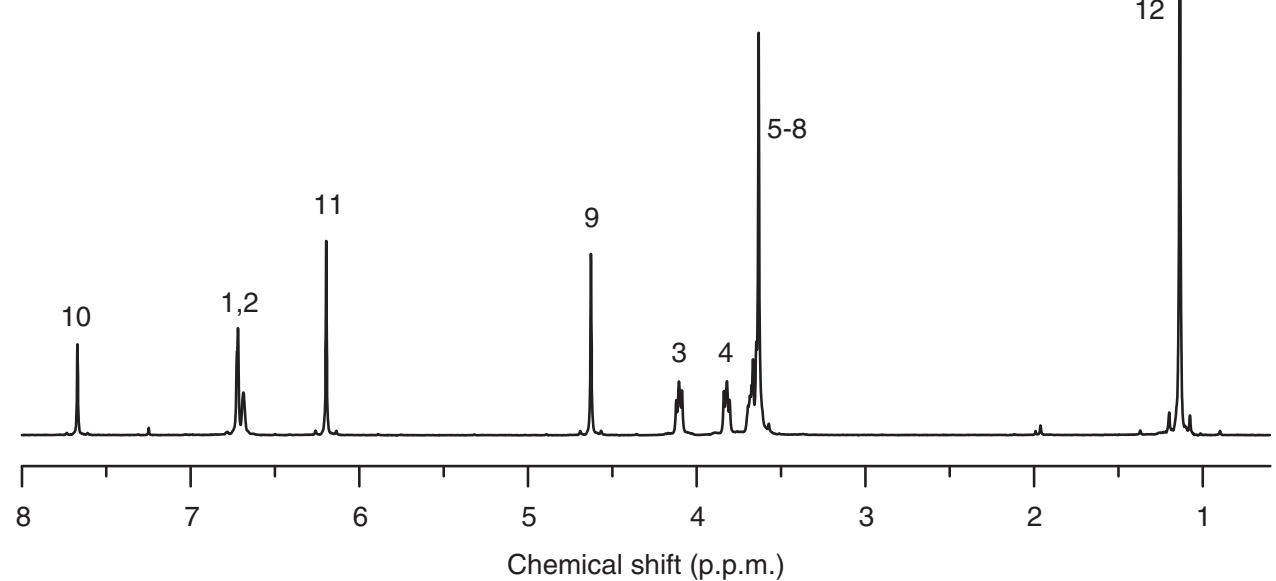

Figure $1^{1} \mathrm{H}$ nuclear magnetic resonance spectrum of compound $6 \mathbf{b}$.

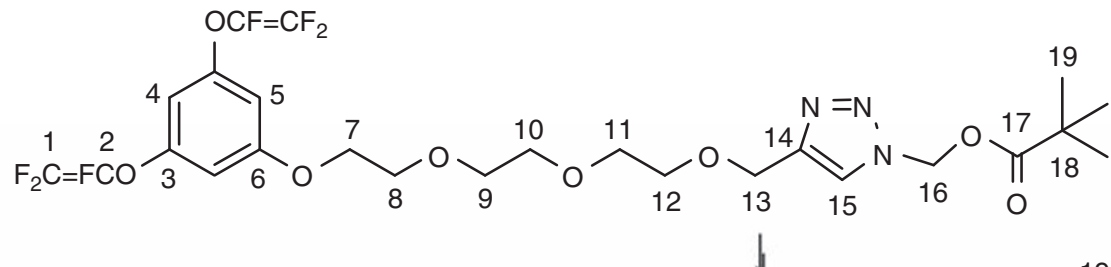
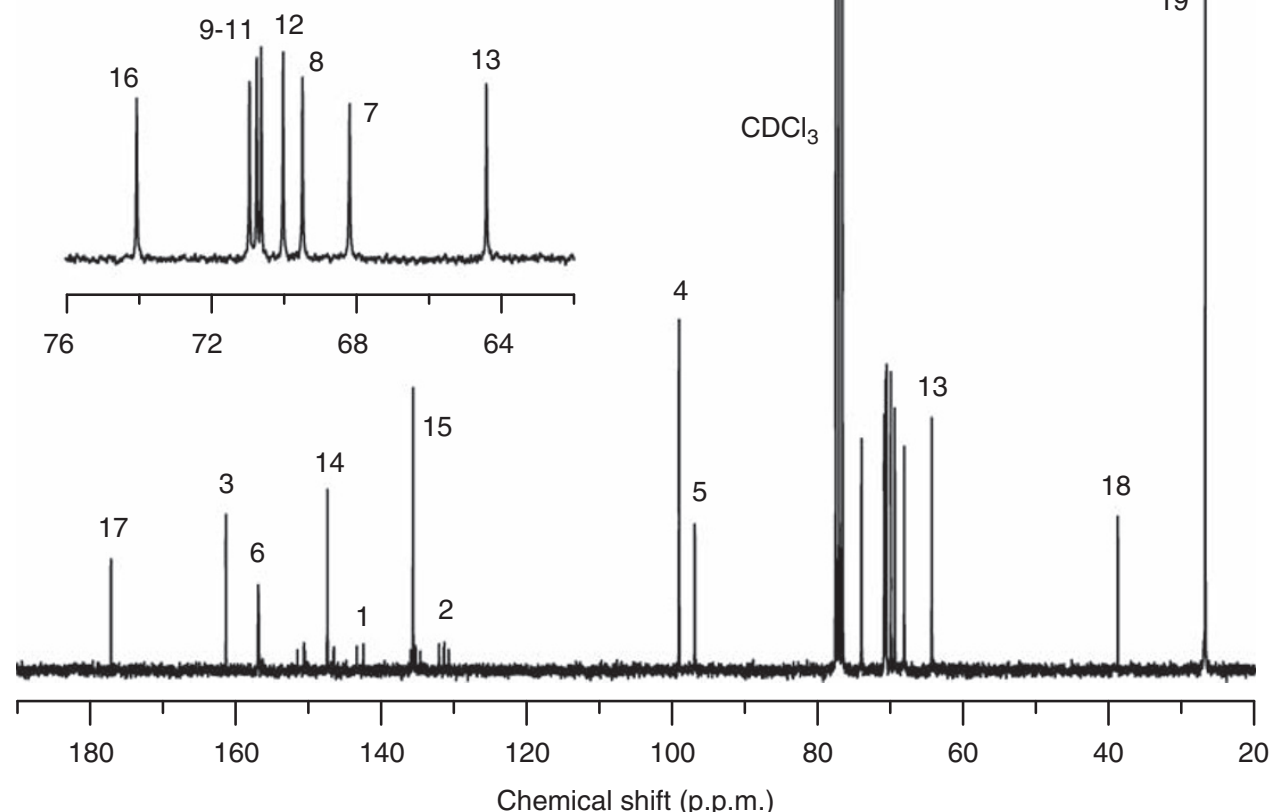

Figure $2{ }^{13} \mathrm{C}$ nuclear magnetic resonance spectrum of compound $\mathbf{6 b}$. 


\section{Polymer syntheses}

The preparation procedures of polymers $\mathbf{7}$ and $\mathbf{8}$ are shown in Scheme 1. polymer 7 was prepared by the thermal $(2 \pi+2 \pi)$ cyclopolymeriza-

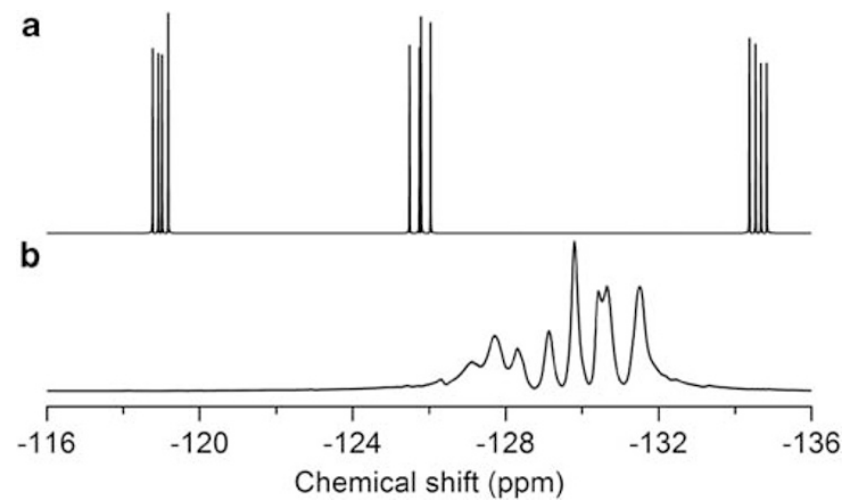

Figure $3{ }^{19} \mathrm{~F}$ nuclear magnetic resonance spectra of (a) compound $\mathbf{6 b}$ and (b) polymer $\mathbf{7 b}$.

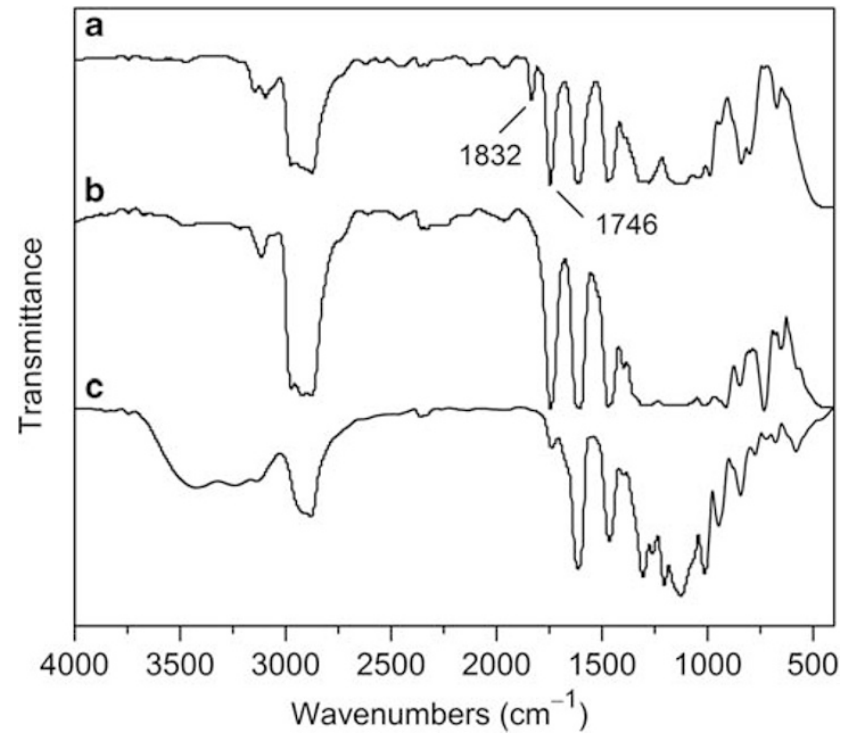

Figure 4 Fourier transform infrared spectra of (a) compound 6 b, (b) polymer $7 \mathrm{~b}$ and (c) polymer $\mathbf{8 b}$. tion of $\mathbf{6}$ in bulk. This polymerization process did not require catalysts or initiators and gave polymer 7 in high yield. The formation of polymer 7 was confirmed by FT-IR, ${ }^{1} \mathrm{H}$ - and ${ }^{19} \mathrm{~F}$ NMR. Polymer $7 \mathbf{b}$ is discussed as a typical example. In the FT-IR spectrum of polymer $7 \mathbf{b}$ (Figure $4 \mathrm{~b}$ ), the sharp band at $1834 \mathrm{~cm}^{-1}$ disappeared, and a new band at $989 \mathrm{~cm}^{-1}$ appeared, which represented the PFCB groups. In Figure $3 \mathrm{~b}$, the resonance signals of the $-\mathrm{OCF}=\mathrm{CF}_{2}$ groups disappeared, and a series of new peaks between -126.7 and -132.1 p.p.m. appeared, which are typical fluorine signals of PFCB groups. The molecular weights of polymer 7 determined by gel permeation chromatography in THF using polystyrene as the standard ranged from 37900 to 38800 for $M_{\mathrm{w}}$ with $M_{\mathrm{w}} / M_{\mathrm{n}}$ values of 2.5-2.8 (Table 1).

Treatment of polymer 7 with $\mathrm{NaOH}$ gave polymer $\mathbf{8}$ in good yield. The conversion of polymer 7 to polymer 8 was confirmed by ${ }^{1} \mathrm{H}$ NMR and FT-IR spectra. The disappearance of the peaks at 1.14 and 6.20 p.p.m. (Figure 5b) indicated the successful removal of the POM moieties, which was further confirmed by the FT-IR spectrum of polymer $\mathbf{8 b}$ (Figure $4 \mathrm{c}$ ). In Figure $4 \mathrm{c}$, a broad band from 2500 to $3500 \mathrm{~cm}^{-1}$ was attributed to the $-\mathrm{NH}$ groups in $1 H-1,2,3$-triazole moieties, and the disappearance of a strong band at $1746 \mathrm{~cm}^{-1}$ indicated the absence of the carbonyl groups in the POM moieties.

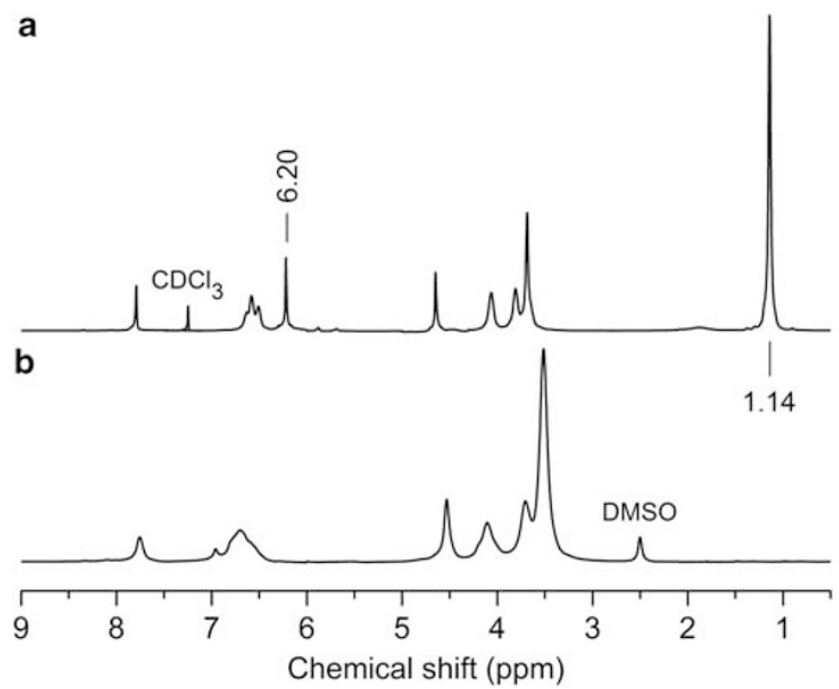

Figure $5{ }^{1} \mathrm{H}$ nuclear magnetic resonance spectra of (a) polymer $7 \mathrm{~b}$ and (b) polymer $\mathbf{8 b}$. DMSO, dimethyl sulfoxide.

Table 1 Properties of polymers 7 and 8

\begin{tabular}{|c|c|c|c|c|c|c|c|c|c|c|}
\hline \multirow[b]{2}{*}{ Polymer } & \multirow[b]{2}{*}{ Triazole (wt\%) } & \multirow[b]{2}{*}{$\mathrm{M}_{w}{ }^{\mathrm{a}}$} & \multirow[b]{2}{*}{$\left(\mathrm{M}_{w} \mathrm{M}_{n}\right)^{\mathrm{a}}$} & \multirow[b]{2}{*}{$\mathrm{T}_{d 5 \%}(C)^{\mathrm{b}}$} & \multirow[b]{2}{*}{$\operatorname{DSC}\left({ }^{\circ} C\right)^{\mathrm{b}}$} & \multicolumn{5}{|c|}{ Solubility } \\
\hline & & & & & & THF & $\mathrm{CHCl}_{3}$ & DMSO & $D M A C$ & $D M F$ \\
\hline $7 a$ & $-^{c}$ & 38800 & 2.5 & 267 & 48 & + & + & + & + & + \\
\hline $7 b$ & $-^{c}$ & 37900 & 2.6 & 274 & 43 & + & + & + & + & + \\
\hline 7c & $-^{c}$ & 38100 & 2.8 & 249 & 36 & + & + & + & + & + \\
\hline $8 a$ & 14.9 & - $^{c}$ & $-^{c}$ & 314 & 110 & - & - & + & + & + \\
\hline $8 b$ & 13.6 & $-^{c}$ & $-^{c}$ & 328 & 97 & - & - & + & + & + \\
\hline $8 c$ & 12.5 & $-^{c}$ & $-^{c}$ & 295 & 89 & - & - & + & + & + \\
\hline
\end{tabular}

Abbreviations: +, soluble; -, insoluble; DMAc, N,N-dimethylacetamide; DMF, dimethylformamide; DMSO, dimethyl sulfoxide; DSC, differential scanning calorimetry; GPC, gel permeation chromatography; TGA, thermo-gravimetric analysis; THF, tetrahydrofuran. chromatography; TGA,
aGPC in THF at $25^{\circ} \mathrm{C}$.

bTGA and DSC at $10^{\circ} \mathrm{C} \mathrm{min}^{-1}$ in $\mathrm{N}_{2}$.

cNot available. 


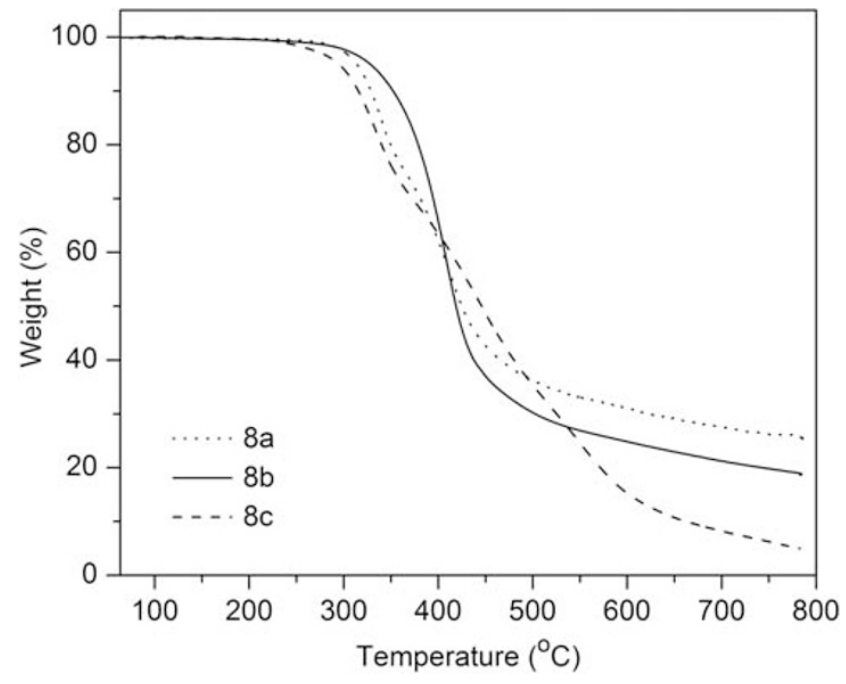

Figure 6 Thermo-gravimetric analysis curves of polymer 8 under nitrogen.

\section{Properties of polymers}

Solubility of polymers. Table 1 shows solubility of the polymers determined quantitatively by dissolving $0.1 \mathrm{~g}$ polymer in $1.0 \mathrm{~g}$ organic solvents. Polymer 7 showed good solubility in common organic solvents such as DMSO, $\mathrm{CHCl}_{3}$ and THF. After removal of POM moieties, however, the resulting polymers (polymer 8) were not soluble in solvents with low dielectric constants and non-polar solvents such as THF and $\mathrm{CHCl}_{3}$, which might be attributed to the strong hydrogen-bonding action between the $1 H$-1,2,3-triazole and oligo(ethylene oxide) units.

Thermal properties of polymers. The thermal properties of the polymers were evaluated by DSC and TGA. As shown in Table 1, the glass transition temperature $\left(T_{\mathrm{g}}\right)$ values of polymer $\mathbf{8}$ were much higher than those of polymer 7 , and the $T_{\mathrm{g}}$ value (polymer 8 ) distinctly decreased with the reduction of the triazole content, which was attributed to the highly hydrogen bonded network formed between the triazole and oligo(ethylene oxide) units. The weight percent of triazole contained in each polymer was calculated by dividing the equivalent weight of the triazole units $\left(68 \mathrm{~g} \mathrm{~mol}^{-1}\right)$ by the equivalent weight of the polymer repeat unit. Figure 6 shows the TGA traces of polymer 8 under nitrogen. These polymers were stable up to $\sim 290{ }^{\circ} \mathrm{C}$, which is much higher than that of previously reported polymers. ${ }^{16,17}$

Proton conductivity. The proton conductivity of polymer 8 was measured from 40 to $200{ }^{\circ} \mathrm{C}$ under anhydrous conditions using impedance spectroscopy. In general, the proton conductivity of polymers containing $N$-heterocyclic moieties is known to be influenced by several factors such as the glass transition temperature of the polymer and the proton charge carrier density. ${ }^{12-14}$ As expected, polymer 8 exhibited very similar conductivity (Figure 7) because they possessed identical polymeric structure. A maximum conductivity of $2.85 \mu \mathrm{S} \mathrm{cm}^{-1}$ was obtained at $200^{\circ} \mathrm{C}$ under anhydrous conditions. The proton conductivities of polymer 8 were lower than the values previously reported, ${ }^{16,17}$ which could be attributed to the higher $T_{\mathrm{g}}$ and lower triazole content of polymer $\mathbf{8}$. The introduction of more than one triazole per repeat unit did not result in an increase in conductivity because there was an accompanying increase in $T_{\mathrm{g}}, 16$ thus, two methods are suggested to improve the proton conductivity. The first one is the reduction of $T_{\mathrm{g}}$ by the incorporation of

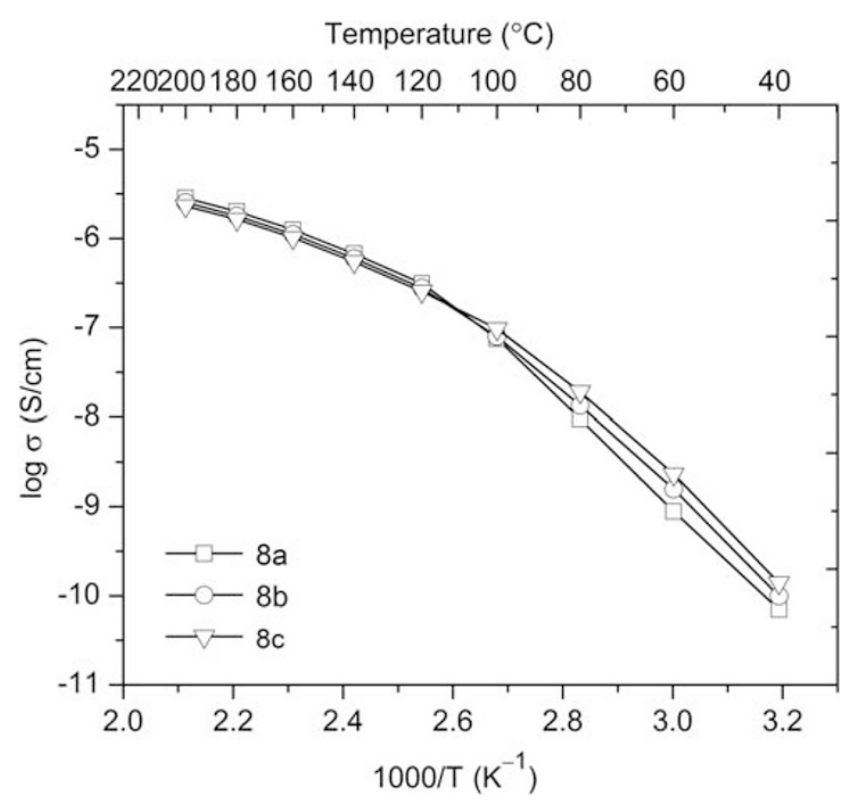

Figure 7 Proton conductivities of polymer 8.

poly(ethylene oxide) (PEO) blocks to prepare copolymers. The second one is the increase of the acidity via the incorporation of electron withdrawing groups such as a trifluoromethyl group into the triazole rings.

\section{CONCLUSIONS}

A new class of perfluorocyclobutyl poly(arylene ether)s containing oligo(ethylene oxide) and $1 H$-1,2,3-triazole units were prepared and characterized. TGA show that these polymers had good thermal stability. DSC analysis indicated that the $T_{\mathrm{g}}$ value of these polymers decreased with the triazole content. These polymers also showed good solubility in common organic solvents such as DMSO and DMF. All polymers exhibited a proton conductivity comparable to that previously reported. ${ }^{16}$ Systematic investigations of these polymers as solid electrolyte membranes for fuel cells applications are in progress.

\section{ACKNOWLEDGEMENTS}

We are grateful to the Doctoral Fund of the Ministry of Education of China (200802551014) and the Open Foundation of State Key Laboratory for Modification of Chemical Fibers and Polymer Materials (LK0804) for financial support.

1 Zhang, J., Xie, Z., Zhang, J., Tang, Y., Song, C., Navessin, T., Shi, Z., Song, D., Wang, H., Wilkinson, D. P., Liu, Z.- S. \& Holdcroft, S. High temperature PEM fuel cells. J. Power Sources 160, 872-891 (2006).

2 de Bruijn, F. A., Makkus, R. C., Mallant, R.K.A.M. \& Janssen, G. J. M. Chapter five materials for state-of-the-art PEM fuel cells, and their suitability for operation above $100^{\circ}$ C. Adv. Fuel Cells 1, 235-336 (2007).

3 Mader, J., Xiao, L., Schmidt, T. J. \& Benicewicz, B. C. Polybenzimidazole/acid complexes as high-temperature membranes. Adv. Polym. Sci. 216, 63-124 (2008).

$4 \mathrm{Li}, \mathrm{Q}$., He, R., Jensen, J. O. \& Bjerrum, N. J. Approaches and recent development of polymer electrolyte membranes for fuel cells operating above $100^{\circ} \mathrm{C}$. Chem. Mater. 15, 4896-4915 (2003).

5 Wang, J. T., Savinell, R. F., Wainright, J., Litt, M. \& $\mathrm{Yu}, \mathrm{H} . \mathrm{A} \mathrm{H} \mathrm{H}_{2} / \mathrm{O}_{2}$ fuel cell using acid doped polybenzimidazole as polymer electrolyte. Electrochim. Acta. 41, 193-197 (1996).

6 Bozkurt, A., Ise, M., Kreuer, K. D., Meyer, W. H. \& Wegner, G. Proton conducting polymer electrolytes based on phosphoric acid. Solid State Ionics 125, 225-233 (1999). 
7 Miyake, N., Wainright, J. S. \& Savinell, R. F. Evaluation of a sol-gel derived Nafion/silica hybrid membrane for proton electrolyte membrane fuel cell applications. J. Electrochem. Soc. 148, A898-A904 (2001).

$8 \mathrm{Pu}$, H., Liu, Q. \& Liu, G. Methanol permeation and proton conductivity of acid-doped poly( $\mathrm{N}$-ethylbenzimidazole) and poly( $\mathrm{N}$-methylbenzimidazole). J. Membr. Sci. 241, 169-175 (2004).

9 Schuster, M., Meyer, W. H., Wegner, G., Herz, H. G., Ise, M., Schuster, M., Kreuer, K. D. \& Maier, J. Proton mobility in oligomer-bound proton solvents: imidazole immobilization via flexible spacers. Solid State lonics 145, 85-92 (2001).

10 Persson, J. C. \& Jannasch, P. Self-conducting benzimidazole oligomers for proton transport. Chem. Mater. 15, 3044-3045 (2003).

11 Jeske, M., Soltmann, C., Ellenberg, C., Wilhelm, M., Koch, D. \& Grathwoh, G. Proton conducting membranes for the high temperature polymer electrolyte membrane fuel cell (HT-PEMFC) based on functionalized polysiloxanes. Fuel Cells 7, 40-46 (2007).

12 Woudenberg, R. C., Yavuzcetin, O., Tuominen, M. T. \& Coughlin, E. B. Intrinsically proton conducting polymers and copolymers containing benzimidazole moieties: glass transition effects. Solid State Ionics 178, 1135-1141 (2007).

13 Zhou, Z., Li, S., Zhang, Y., Liu, M. \& Li, W. Promotion of proton conduction in polymer electrolyte membranes by $1 \mathrm{H}$-1,2,3-triazole. J. Am. Chem. Soc. 127, 10824-10825 (2005).

14 Subbaraman, R., Ghassemi, H. \& Zawodzinski, T. A. Jr 4,5-Dicyano-1 H-[1,2,3]-triazole as a proton transport facilitator for polymer electrolyte membrane fuel cells. J. Am. Chem. Soc. 129, 2238-2239 (2007).

15 Martwiset, S., Woudenberg, R. C., Granados-Focil, S., Yavuzcetin, O., Tuominen, M. T. \& Coughlin, E. B. Intrinsically conducting polymers and copolymers containing triazole moieties. Solid State lonics 178, 1398-1403 (2007).

16 Martwiset, S., Yavuzcetin, O., Thorn, M., Versek, C., Tuominen, M. \& Coughlin, E. B. Proton conducting polymers containing $1 \mathrm{H}$-1,2,3-triazole moieties. J. Polym. Sci. Part A Polym. Chem. 47, 188-196 (2009).
17 Nagamani, C., Versek, C., Thorn, M., Tuominen, M. T. \& Thayumanavan, S. Proton conduction in $1 \mathrm{H}$-1,2,3-triazole polymers: imidazole-like or pyrazole-like? J. Polym. Sci. Part A Polym. Chem. 48, 1851-1858 (2010).

18 Frutsaert, G., Delon, L., David, D., Ameduri, B., Jones, D., Glipa, X. \& Roziers, J. Synthesis and properties of new fluorinated polymers bearing pendant imidazole groups for fuel cell membranes operating over a broad relative humidity range. J. Polym. Sci. Part A Polym. Chem. 48, 223-231 (2010).

19 Babb, D. A., Ezzell, B. R., Clement, K. S., Richey, W. F. \& Kennedy, A. P. Perfluorocyclobutane aromatic ether polymers. J. Polym. Sci. Part A Polym. Chem. 31, 3465-3477 (1993).

20 Smith, D. W. Jr, Babb, D. A., Shah, H. V., Hoeglund, A., Traiphol, R., Perahia, D., Boone, H. W., Langhoff, C. \& Radler, M. Perfluorocyclobutane (PFCB) polyaryl ethers: versatile coatings materials. J. Fluorine Chem. 104, 109-117 (2000).

21 Zhu, Y., Huang, Y., Meng, W.- D., Li, H. \& Qing, F.- L. Novel perfluorocyclobutyl (PFCB)containing polymers formed by click chemistry. Polymer 47, 6272-6279 (2006).

22 Ford, L. A., DesMarteau, D. D. \& Smith, D. W. Jr Perfluorocyclobutyl (PFCB) aromatic polyethers: synthesis and characterization of new sulfonimide containing monomers and fluoropolymers. J. Fluorine Chem. 126, 651-658 (2005).

23 Kim, D.- J., Chang, B.- J., Kim, J.- H., Lee, S.- B. \& Joo, H.- J. Sulfonated poly(fluorenyl ether) membranes containing perfluorocyclobutane groups for fuel cell applications. J. Membrane Sci. 325, 217-222 (2008).

$24 \mathrm{Lu}, \mathrm{G} .$, Lam, S. \& Burgess, K. An iterative route to 'decorated' ethylene glycol-based linkers. Chem. Commun. 2006, 1652-1654 (2006).

25 Loren, J. C., Krasinski, A., Fokin, V. V. \& Sharpless, K. B. NH-1,2,3-triazoles from azidomethyl pivalate and carbamates: base-labile $\mathrm{N}$-protecting groups. Synlett $\mathbf{2 0 0 5}$, 2847-2850 (2005).

26 Li, J., Qiao, J., Smith, D., Chen, B., Salvati, M. E., Roberge, J. Y. \& Balasubramanian, B. N. A practical synthesis of aryl tetrafluoroethyl ethers via the improved reaction of phenols with 1,2-dibromotetrafluoroethane. Tetrahedron Lett. 48, 7516-7519 (2007). 